\title{
THE NORDIC COUNCIL
}

Founded in 1952 as a co-operative link between the parliaments and governments of the Nordic states. The co-operation focuses on Intra-Nordic co-operation, cooperation with Europe/EU/EEA and co-operation with the adjacent areas. The Council consists of 87 elected MPs and the committees meet several times a year, as required. Every year the Nordic Council grants prizes for literature, music, nature and environment.

Members. Denmark (including the Faroe Islands and Greenland), Finland (including Åland), Iceland, Norway, Sweden.

Address: Postboks 3043, DK-1021 Copenhagen K, Denmark.

Website: http://www.norden.org/

President: Inge Lønning (Norway).

\section{NORDIC DEVELOPMENT FUND (NDF)}

Established in 1989, the NDF is a development aid organization of the five Nordic countries, Denmark, Finland, Iceland, Norway and Sweden. NDF capital totals SDR $515 \mathrm{~m}$. and $€ 330 \mathrm{~m}$. Credits are offered to developing countries, with poorer African, Asian and Latin American countries taking priority.

Address: Fabianinkatu 34, PO Box 185, FIN-00171 Helsinki, Finland.

Website: http://www.ndf.fi

e-mail: info.ndf@ndf.fi

President: Jens Lund Sørensen (Denmark).

\section{NORDIC INVESTMENT BANK (NIB)}

The Nordic Investment Bank, which commenced operations in August 1976, is the joint international financial institution of the Nordic countries. It finances investment projects and project exports both within and outside the Nordic area. Priority is given to investment and environmental loans for projects in the Baltic states, Poland and northwest Russia.

Address: Fabianinkatu 34, PO Box 249, FIN-00171 Helsinki, Finland.

Website: http://www.nib.int

President: Jón Sigurdsson (Iceland).

\section{COUNCIL OF THE BALTIC SEA STATES}

Established in 1992 in Copenhagen following a conference of ministers of foreign affairs.

Members. Denmark, Estonia, Finland, Germany, Iceland, Latvia, Lithuania, Norway, Poland, Russia, Sweden and the European Commission.

Aims. To promote co-operation in the Baltic Sea region in the field of trade, investment and economic exchanges, combating organized crime, civil security, culture and education, transport and communication, energy and environment, human rights and assistance to democratic institutions.

The Council meets at ministerial level once a year, chaired by rotating foreign ministers; it is the supreme decision-making body. Between annual sessions the 